\title{
形態改質繊維アラカルト（その 1$)$
}

このシリーズは, 各社の製品紹介として, 繊維の構造, 形状を改質した化学瀻維の中から,ここ 1 年間 に開発された代表的な絨維を選んで執筆をいただき，順次掲載していく予定です，内容は，開発の狙い， 製法, 形能 (写真), 特徵, 用途から成っています.

\section{慗品紹介}

\section{コンジュゲート技術による超極細ナイロン「グラセム ${ }^{\circledR} 」$}

$\begin{array}{ccc}\text { 鐘 紡 } & \text { 市橋 } & \text { 邦夫 } \\ \text { " } & \text { 武田 俊英 }\end{array}$

\section{1. はじめに}

「グラセム ${ }^{\circledR} 」 は$ 鐘紡の優れたコンジュゲート紡 糸技術と加工技術の結合によって生み出された超極 細ナイロンであり, ナイロン一般編織物では初の 0.18 デニールの単糸が得られたのである.

「グラセム」はナイロン織物の静かなブームが続 く中で, 特殊差別化, 高感度を求めるアパレルの二 ーズに対応するハイテク, ハイタッチ素材として注 目されている. 超ドレープ性, 超ソフト, シルキー な光沢を持つ素材として好評を得ており, 幅広い用 途開発と今後の成長が期待できる素材である.

\section{2.「グラセム」開発の背景}

コンジュゲート瀻維は，その形態や製法から芯鞘 型, 多分散型, 接合型等に分類1できる.

当社のコンジュゲート技術はその歴史が古く,ナ イロンの事業化と同時に検討を始めている.例えば, 芯鞘型ではポリエステルを芯とし，ナイロンを鞘と した複合糸を初期のシルキー合織として市場に出し ている.

多分散型は， 2 種の高分子物の一方が他方の成分 中に星雲状に分散し, 長さ方向に実質的に連続した 混合フィラメントを形成させる夕イプのものであ り, 古くから開発を進め ${ }^{2.3)}$, 紡系工程における分散 状態の制御技術を確立し，制電ポリエステル「ソア リス $\mathrm{P}^{\circledR}$ 等多方面に応用している.

接合型(4゙は, まず 2 層構造のものとして, ナイ ロンの 2 つ異なるポリマーを複合化し, いわゆる ポリマーの収縮差を利用した潜在捲縮糸による「ナ

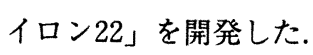

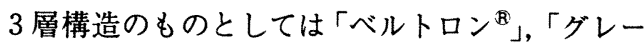
ベルトロン®等が制電系として実用化されており, 市場で高い評価を得ている.

一方, 接合型の変形である当社独自のものとして, 2 成分フィラメントによるセグメント分割型を開

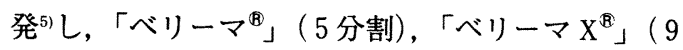
分割）を発表した.「ベリーマX」は $0.67 \mathrm{~d}$ のナイ ロンと $0.17 \mathrm{~d}$ のポリエステルに分割されるタイプ で, 人エスエードの「ベルセイム風界初の非 コーティング型透湿防水布「ザヴィーナ」シリー ズ用の原系として,広範な商品展開に成功している. これらの開発と生産を通じて蓄積した技術ノウハウ 及び加工設備を駆使して, 画期的な新感覚素材「グ ラセム」の誕生が可能となったわけである.

これらのコンジュゲート技術を応用した繊維, と りわけ超極細瀻維を用いた製品は今日の市場で確固 たる地位を占めており, 多数の製品が市場6に出さ れているが, 超極細瀻維を効率良く編織物にするこ とは意外に困難であり，これとらの多くは，まず人 工皮革や人エスエードの分野から実用化され，一般 の編織物への展開は，「ザヴィーナ $\mathrm{DP}^{\circledR} 」 て ゙$ 代表さ れる「ザヴィーナ」シリーズ7や「グラセム」を除 けば，まだ実用例は少ないといえる.

技術面では, ウールライク加工糸織物,「フラノ $21 」$ に使用されている「ベリーマ」や人エスェード「ベ ルセイム」や超高密度織物「ザヴィーナ DP」等に 使用されている「ベリーマX」の延長線上にあり， これらの原緎技術や加工のノウハウが大きく生かさ れている. 


\section{3.「グラセム」の製法及び特徴}

「グラセム」の原糸は, 図 1 の模式図に示すよう に，8本の分割できるナイロンを主な構成要素とし
たコンジュゲート繊維であり，超易溶性のポリエス テルが 8 本のナイロンを貼合せたような形態になっ ている，構成割合は，ナイロン部分が $75 \%$ ，ポリエ ステル部分が $25 \%$ であので，例えば， $100 \mathrm{~d} ， 50$

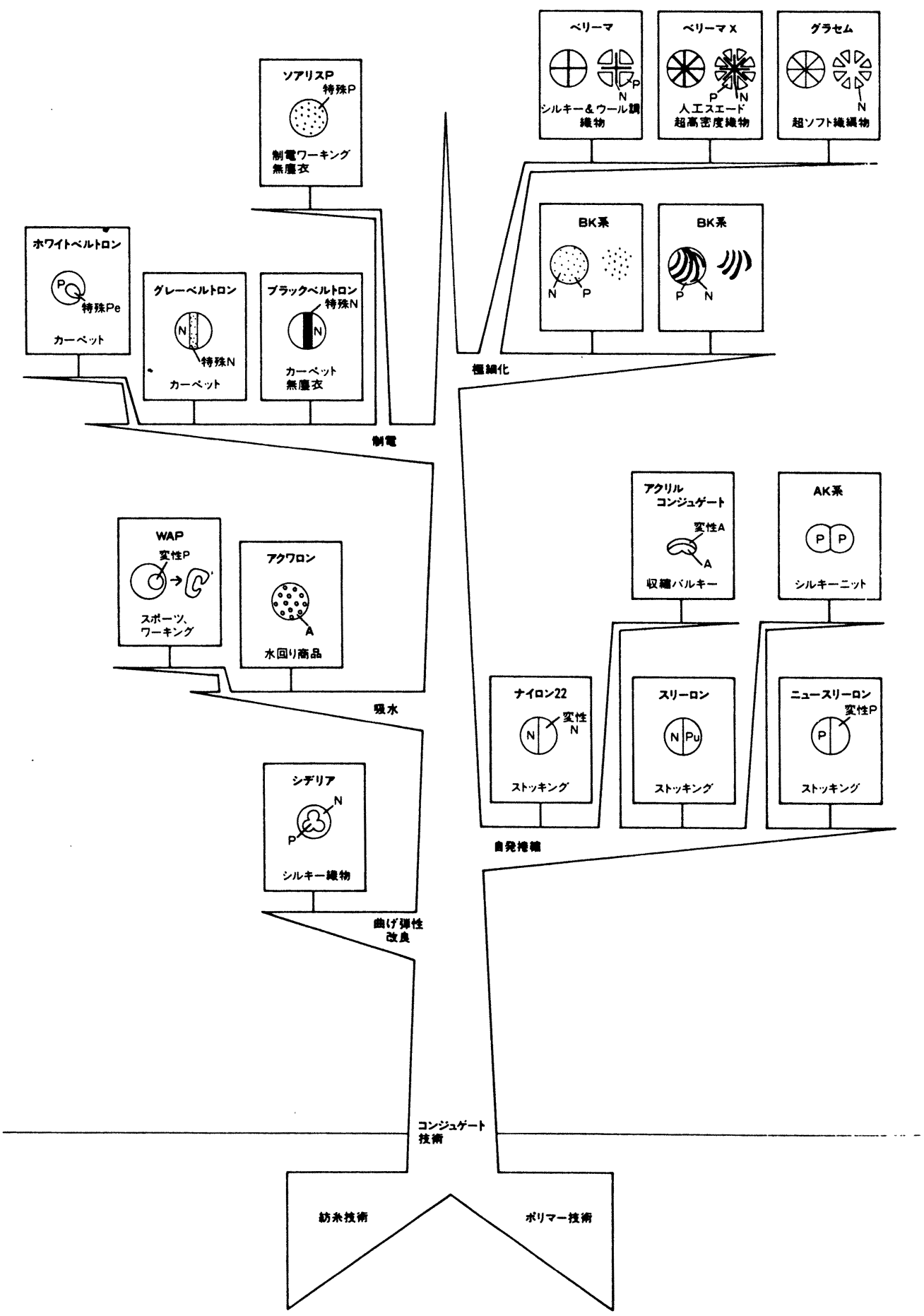

図 1 コンジュゲート紡系技術 
(繊維工学) Vol. 39, No. 10 (1986)

フィラメントの原系をアルカリで処理して超易溶性 のポリエステルを除去（図 2 ）すると, 糸は $75 \mathrm{~d}$ になり，400フィラメントに割繊されるので， 0.18 d という超極細のナイロンが得られるわけである. 通常, このアルカリ処理は, 編織物になってから行 われる.

従って割繊前の太い繊度で編織機に掛けられるの で，効率良くファブリックの形に加工ができる. 瀻 維の断面は電子顕微鏡写真に示すようなミクロン単 位の, 精密な花弁状に成型されている（図 3，4）. しかも長さ方向やフィラメント間の性状のバラッキ がなく，たてすじ等の不良が発生しない.

このようにして, 織編物の形になった「グラセム」 は図 5 に示すごとくバルキー性に富み, しかも複雑 な断面形状となるために、「グラセム」特有の超ソ フト風合いと深みのある光沢を兼ね備える素材とな る.

ポリエステル部分を除去した後はナイロン繊維 100\%となるため, 通常のナイロン加工と同様の方 法で, ヒートセット加工, 染色 ${ }^{8.91}$, カレンダ, エン ボス等の付帯加工が可能である.「グラセム」は通常, 酸性染料等のイオン結合型染料で染色されるため, ポリエステル系の極細繊維で論議されている分散染 料の移行昇華の問題が皆無であるため, 安心して, 各種のコーティング加工用の基布としても使用でき る.ナイロンはポリエステルに比べて低ヤング率, 低比重であるため同程度の繊度であればポリエステ ルよりもソフトな風合いを示し, 同じ厚さなら軽量

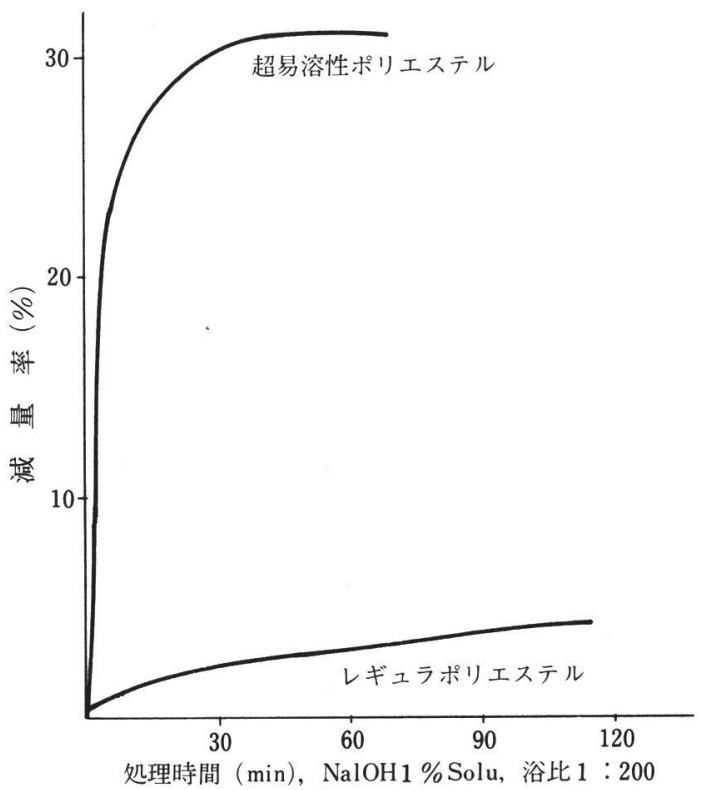

図 2 ポリエステル成分のアルカリ隇量速度

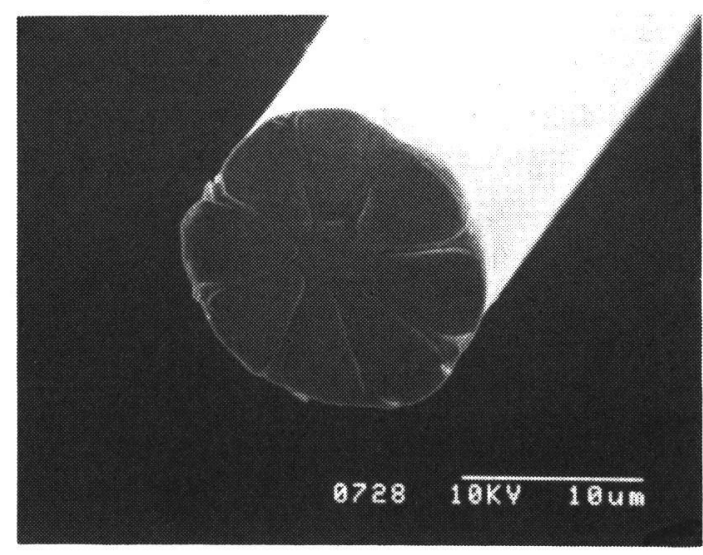

図 3 「グラセム」の原系

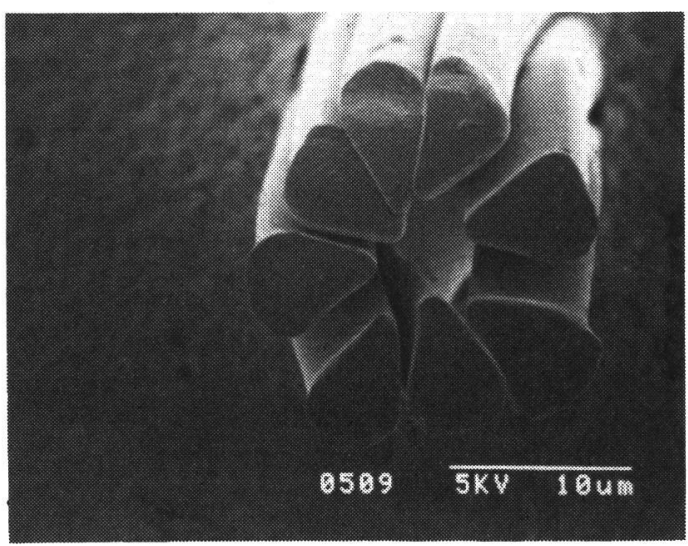

図 4 割㵶後の「グラセム」糸

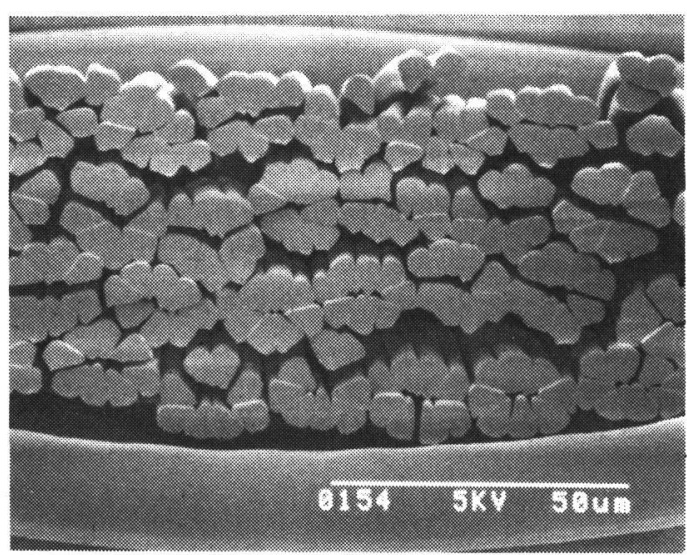

図 5 「グラセム」織物の断面

になる。そして，酸性染料で常圧下で染色可能であ り，ポリエステルに用いられる分散染料よりも鮮明 な色相が得られる。, 又, 割繊には特殊な有機溶剤は 必要とせず, アルカリ処理により簡単に実施できる 等多くの利点を持っている. 
ここで，グラセムの特徴をまとめると次の通りで ある.

(1)75 d/400 f という超ハイマルチナイロンフィラ メント糸の編織物であるため, シルクを越えた ソフトな風合いと豊かなドレープ性を持つ.

(2)合織に特有のガサツキ音がない.

(3)三角断面が花弁状に集まっているために，天然 のシルクに匹敵するマイルドで上品な光沢を持 っている.

(4)複雑な断面形状によって光の乱反射が起こるた め, 光の透過率が低く, 薄地でも透け難い優れ た不透明性を有する（図 6 ）。

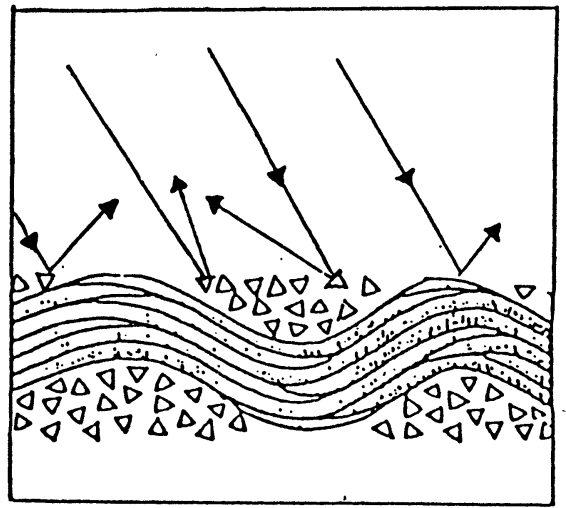

図 6 「グラセム」織物の断面図と光の乱反射

(5)素材がナイロンであるため，コーティング樹脂 への染料の泣き出し（移行昇華現象）が起こら ない.

(6)しわ, ワッシャなどの高次加工によって新しい

風合いが次々と表現できる.

等, 多くの優れた特性を持っている.

また，製品の物性面ではウルトラファイン製品に もかかわらず, 引張強力, 引裂強力, 洗濯収縮率, 繰返し洗濯による強度保持率等はレギュラタイプの ナイロンとほとんど変らず，合織布帛本来の優れた 特性をそのまま維持している.

\section{4.「グラセム」の展開及び用途}

「グラセム」は以上の特性によって, ナイロンの
用途を大幅に拡大し，ナイロン新時代を切開く大型 素材である.「グラセム」の用途を次に示す.

・スポーツウェア（スキー,トレーニングウェア, ウィンドブレーカ)

・ドレス，ブラウス（螮人）

・コート（紳士，婦人）

・カジュアル（紳士，婦人）

・その他インナウェア, 傘地等

\section{5.おわりに}

以上に述べたごとく「グラセム」は風合い, 感性 及び機能の面でユニークで優れた特性を持ってお り，ハイテク，ハイタッチ素材として，その用途を 大きく広げられる可能性を秘めた素材である. 自然 現象を学ぶ中に商品開発へのヒントが存在するとい われている昨今, コンジュゲート技術の革新と, 絹 の精練機構を応用した割繊技術は, まさに時流に適 合しており，その成長が大いに期待できる. 現在は 主としてナイロン $100 \%$ で展開を行っているが, 他緎維, 特に当社が得意としている天然㵶維との複 合化を志向しており, 複合化時代を先取りし, 多様 化したユーザのニーズに対応できる素材として育て たい.

\section{引用文献}

1)䄉維学会, 「図説 織維の形態」P176 (1982)

2）特公昭, 47-45607

3）特公昭, 48-16449

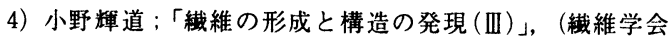
編), 化学同人, p. 41 101 (1971)

5）特公昭，48-37044

6）大阪ケミカルマーケッティングセンター, Vol. 3, No. 88, 「ウルトラ・ファイン・ファイバーの新しい段階」p. 184 (1984)

7）䄉維科学, 高機能性素材特集, 「ザヴィーナ製品シリーズ』 (別冊1985)

8）林茂助；「染色加工講座 5 」（共立出版編） p. 214 238 (1965)

9）寺田商太郎；桟維加工 (染色入門講座)，32, No. 2, 97 (1980)

10）中村健；加工技術，15，10（1980） p. 9 14 